\title{
THE CARTOGRAPHIC METHOD OF RESEARCH IN EXPLORING THE REAL ESTATE MARKET - A CASE OF USING MAPS FOR THE INTRODUCTORY ANALYSES OF THE LUBLIN SUBURBAN COMMUNE OF KONOPNICA
}

\author{
Kamil Nieścioruk, PhD \\ Department of Environment Engineering and Geodesy \\ University of Life Sciences in Lublin \\ e-mail:kamil.niescioruk@up.lublin.pl
}

\begin{abstract}
The paper deals with the introductory analysis of the real estate market of a suburban commune located near a big (voivodeship capital) city. The analysis is based mainly of the cartographic method of research. Besides data mining and preparation, maps play an important role here, presenting values acquired directly from the register of notarial deeds of estate sales and purchases, as well as values resulting from statistic computation, for example mean values of area or price, absolute numbers of transactions or real estate type. The spatial factor is also taken into consideration when it comes to more complex or specific analyses. The influence of distance understood as a metric and time factor, as well as regression analysis results are also visualized on maps. Such presentation is a good step towards advanced analyses providing maps are prepared according to the rules of cartography. The paper stresses that a map can be a great tool in aiding every stage of research, but may also cause misinterpretations and false conclusions when at least basic rules are not complied with.
\end{abstract}

Key words: cartography, GIS, suburban, cartographic method of research, methodology.

JEL Classification: Y91.

Citation: Nieścioruk K., 2015, The Cartographic Method of Research in Exploring the Real Estate Market - a Case of Using Maps for the Introductory Analyses of the Lublin Suburban Commune of Konopnica, Real Estate Management and Valuation, Vol. 23, No. 2, pp. 17-26.

DOI: 10.1515/remav-2015-0012

The real estate market is, as every other market, defined by its object prices and economic elements of supply and demand influencing these prices. Real estate appraisal is a process of answering three questions of: what is being evaluated, why it is being evaluated and on what basis (CYMERMAN, HOPFER 2012). The list of factors influencing price can be very long, but the main groups are (KUCHARSKA-STASIAK 2006, p. 130):

- environmental,

- economic,

- legal,

- demographic,

- political,

- social,

- other specific.

Most of these factors are, to some extent, characterized by a spatial context. The spatial context of demography or the environment is obvious, but also the economy and other factors are more or less 
spatially dependent. This means that real estate market analysis can be based on, as well as supplemented and preceded by the use of spatial methods, e.g. the cartographic method of research. This is a procedure of obtaining new information and knowledge from a set of data presented on a map using professional knowledge and, most importantly, a specific approach (SALISZCZEW 1998, pp. 265-266). The popularity of this method increased with the use of Geographic Information System (GIS) software, even if the term itself is not well-known among GIS users. Both GIS and the cartographic method of research is present in the field of real estate appraisal, as a map can clearly and easily show relations, helping one to understand the factors that can influence prices. Hence, maps are very good tools in both, introductory analysis and the appraisal process, as well as at the stage of presenting the spatial distribution of prices, factors and the relationships between them. Maps were often used in the latter case, serving as illustrations of a certain state and situation; however, their use in the process of research is also becoming increasingly popular (CICHOCIŃSKI 2007; CICHOCIŃSKI, DĄBROWSKI 2013). This paper concentrates on the use of maps in the introductory analysis of the real estate market of a suburban gmina (commune).

\section{The area of research}

The area encompassed by the case study is the Polish commune of Konopnica. It is located in the voivodeship of Lublin, just west of its capital, the city of Lublin. The commune has a population of over 12.5 thousand and covers an area of 93 square kilometres, resulting in a density of 135 people per $\mathrm{km}^{2}$ (POWIERZCHNIA... 2013, p. 76), which is higher than the national average. The commune consists of the following villages: Konopnica, Kozubszczyzna (seat of the commune), Lipniak, Marynin, Motycz, Motycz-Józefin, Motycz Leśny, Pawlin, Radawczyk Drugi, Radawiec Duży, Radawiec Mały, Sporniak, Stasin, Szerokie, Tereszyn, Uniszowice, Zemborzyce Dolne, Zemborzyce Podleśne, Zemborzyce Tereszyńskie and Zemborzyce Wojciechowskie. The map of the commune has been shown in Figure 1.

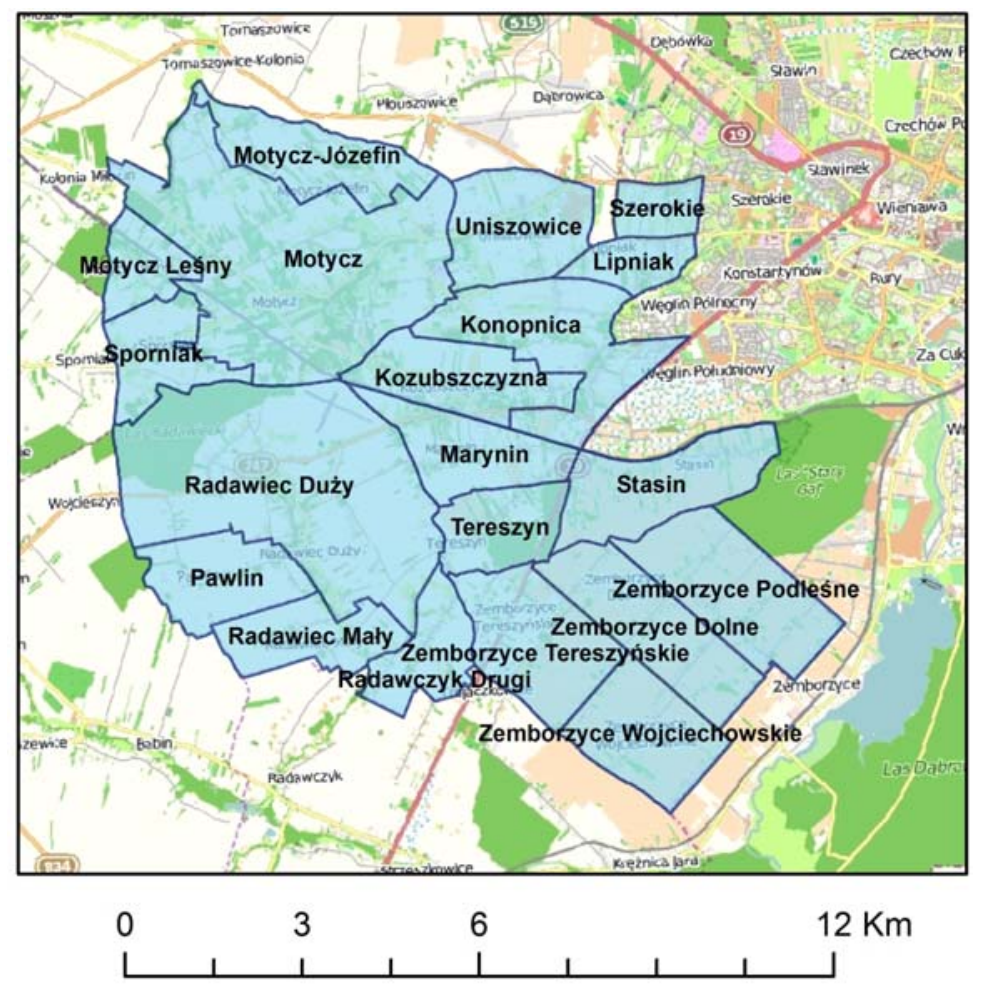

Fig. 1. The villages of the commune Konopnica in the neighborhood of Lublin (seen to the east), based on a reference map retrieved from OpenStreetMap (@ OpenStreetMap authors, Open Database Licence CC-BY-SA).

The commune has been chosen as the area of the case study because it has a dynamic real estate market, typical of suburban areas. Especially the villages of Konopnica, Lipniak and Szerokie are attractive for well-off citizens of Lublin and have been turned into a residential area located just west of the border of Lublin, with easy and fast access to the city, as is the case in similar villages of other 
communes near Lublin, for example Niemce, Jastków or Głusk (IWANICKI 2012, pp. 83-84). The prices of land here are very high, contrary to villages in the western part of the commune, for example Pawlin or Sporniak. These villages are not far from Lublin either, but are not as popular or, as one might put it - fashionable, as those mentioned earlier, and fashion is an additional factor on every market, the real estate market being no exception (TROJANEK 2009). In terms of demography, the commune is a typical example of an area lying near a big city. The overall change in the population of Konopnica over the last decade is positive, with growth generated mainly by the migration balance, its value reaching 18 per 1000 persons, in contrast to almost 0 for the rate of natural increase (MARKOWSKI 2014, p. 60). With Lublin characterized by a positive rate of natural increase and negative migration, this clearly shows that the commune is one of the areas where the inhabitants of Lublin migrate to, similarly to other communes in its vicinity. In addition to this, people from communes of the voivodeship migrate to Konopnica, as well as residents of other voivodeships, and not only. Over the years 1995-2009, 90.3\% of all inhabitants of Konopnica were born in the Lublin voivodeship, with $69 \%$ coming from the actual city of Lublin; $8.7 \%$ were born outside the voivodeship and $1 \%$ came from abroad (IWANICKI 2012, pp. 85-86).

\section{Data preparation}

The primary source of information regarding the real estate market was the official list of the register of notarial deeds of estate sales and purchases (rejestr cen i wartości nieruchomości). The analyzed transactions took place during a period of 3 years, i.e. 2010 to 2012. A total number of 649 transactions were recorded. Table 1 contains detailed information on the number of transactions.

Table 1

Number of analyzed transactions

\begin{tabular}{|c|c|c|c|c|}
\hline \multirow[b]{2}{*}{ Village } & \multicolumn{4}{|c|}{ Number of transactions } \\
\hline & Total & $\begin{array}{r}\text { Built-up } \\
\text { agricultural }\end{array}$ & $\begin{array}{l}\text { Non-built-up } \\
\text { agricultural }\end{array}$ & $\begin{array}{l}\text { Other (non- } \\
\text { agricultural) }\end{array}$ \\
\hline Konopnica & 115 & 3 & 85 & 27 \\
\hline Kozubszczyzna & 30 & 0 & 20 & 10 \\
\hline Lipniak & 34 & 0 & 32 & 2 \\
\hline Marynin & 28 & 5 & 17 & 6 \\
\hline Motycz & 120 & 7 & 86 & 27 \\
\hline Motycz-Józefin & 21 & 1 & 19 & 1 \\
\hline Motycz Leśny & 12 & 1 & 10 & 1 \\
\hline Pawlin & 3 & 0 & 3 & 0 \\
\hline Radawczyk Drugi & 6 & 0 & 6 & 0 \\
\hline Radawiec Duży & 70 & 9 & 55 & 6 \\
\hline Radawiec Mały & 13 & 0 & 13 & 0 \\
\hline Sporniak & 15 & 0 & 15 & 0 \\
\hline Stasin & 16 & 1 & 12 & 3 \\
\hline Szerokie & 34 & 1 & 26 & 7 \\
\hline Tereszyn & 17 & 2 & 10 & 5 \\
\hline Uniszowice & 46 & 2 & 26 & 18 \\
\hline Zemborzyce Dolne & 15 & 1 & 13 & 1 \\
\hline Zemborzyce Podleśne & 29 & 1 & 25 & 3 \\
\hline $\begin{array}{l}\text { Zemborzyce } \\
\text { Tereszyńskie }\end{array}$ & 12 & 1 & 7 & 4 \\
\hline $\begin{array}{l}\text { Zemborzyce } \\
\text { Wojciechowskie }\end{array}$ & 13 & 2 & 11 & 0 \\
\hline Total & 649 & 37 & 491 & 121 \\
\hline
\end{tabular}

Source: own study.

The register contained more entities than the above-mentioned 649, but a few had to be rejected for various reasons. Some of them lacked proper information regarding the price (only the total was given 
for two or more different real estates, sometimes in different villages or of a different type), or the type or values provided were clearly a typo (lack of one digit in the price).

\section{Analysis and maps}

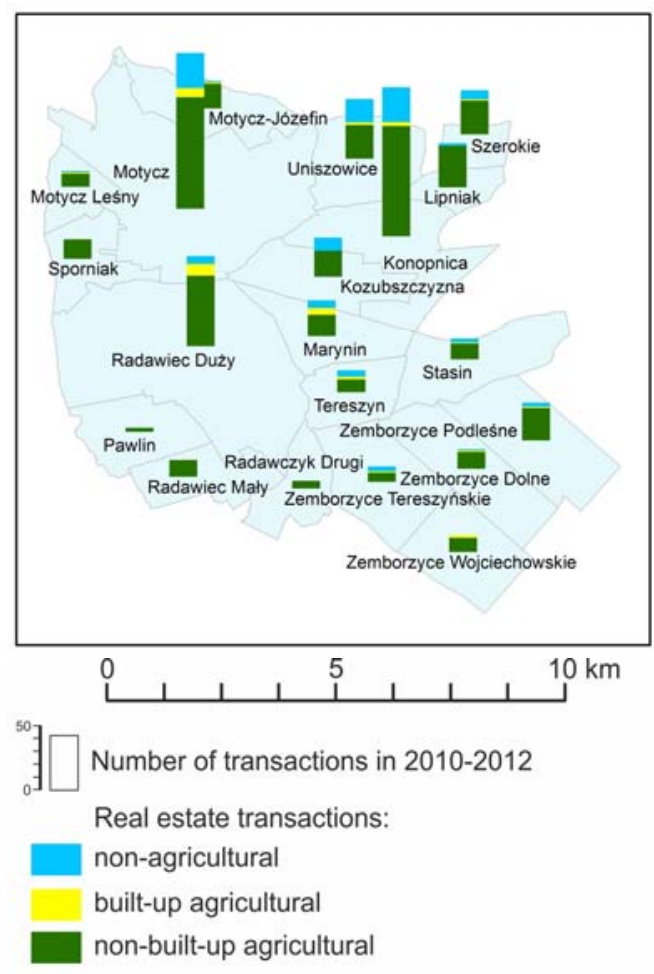

Fig. 2. The number and structure of real estate transactions in the commune of Konopnica. Source: own study.

As it was mentioned, maps are powerful tools in every step of analysis. They help in understanding the analyzed phenomena at an introductory stage of data mining and preparation, finding the answer to the question being the result of the main research process and illustrating the outcomes of this research at the final stage of work. Table 1 above can be easily converted into a map, providing not only precise numbers (as in the diagram method) but also the spatial distribution of the value in a way that illustrates the spatial connections between data sets and areas. What can be seen in Figure 2 is the domination of transactions involving agricultural real estates (green and yellow), especially un-built ones (green). It also shows there are 3 dominant villages in terms of the number of transactions (Konopnica, Motycz and Radawiec Duży) as well as illustrating that villages close to the border of Lublin are areas characterized by significantly larger numbers of transactions (for example Szerokie, Lipniak, Kozubszczyzna, Zemborzyce Podleśne or the earlier mentioned village of Konopnica) than in most of the villages located further west (e.g. Motycz Leśny, Sporniak, Pawlin, Radawiec Mały); the later was not a strict rule, however, as demonstrated by Motycz with a total of 120 transactions. This image raises the question of the reason behind such a distribution. With the domination of agricultural real estates, the reason could be the different quality of soil. However, this is not the case. Over $90 \%$ of soils in the commune of Konopnica are of very good or good (class II or IIIa) quality (GLEBY), and the commune has the highest index of resources of agricultural production space in the Lublin region, i.e. 103.1 (WITEK 1993). Keeping in mind that the commune is a popular area of migration for the better-off inhabitants of Lublin, who work in the city and visit it frequently, and the fact that over $50 \%$ of construction permits were issued for citizens of Lublin (WESOŁOWSKA 2006, p. 47), it can be assumed that at least some of these properties were bought with the intention of converting them into residential housing. In such a case, one of the main factors defining the price of real estate is its location in relation to the city and to the network of communication - main road providing fast and convenient means of accessing the city. As can be seen in Figure 3, there is a relationship between the popularity of a given village (understood as the number of transactions) and 
the road network. Villages next to the border of Lublin are serviced by the city's road network, but more distant ones are dependent on other roads. Motycz and Radawiec Duży have a few roads passing through their area, which makes these communes attractive for Lublin residents due to the good transport connection.

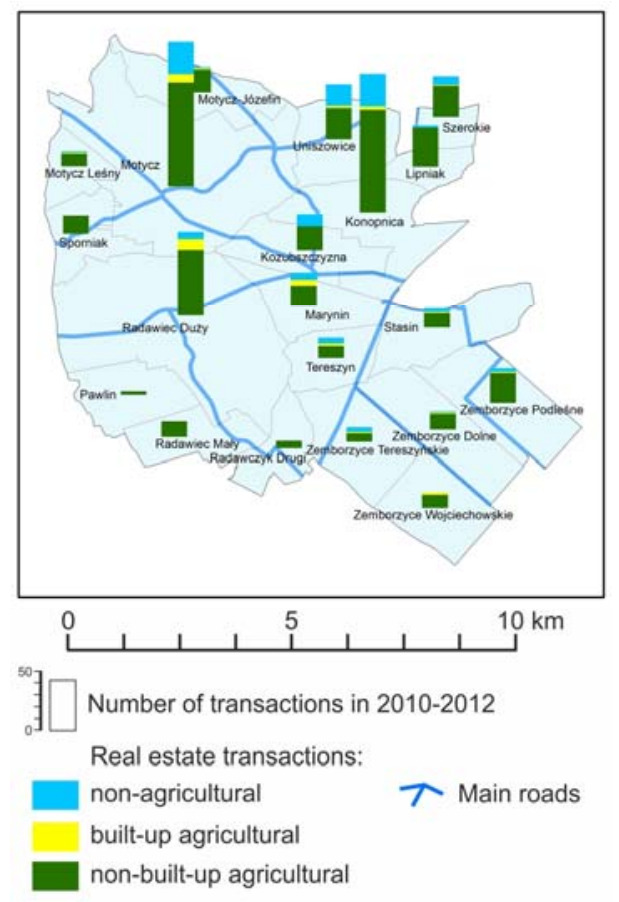

Fig. 3. The number and structure of real estate transactions in the commune of Konopnica supplemented by a road network (Top 5 of 7 road classes from the TBD database included). Source: own study.

While the number of transactions reflects the popularity of an area, it can be illustrated even better by their price. There are no data to assess the number of agricultural estates that are turned into residential ones, but their price can be a good indicator in the case of areas with high residential potential (MAĆKIEWICZ 2009). In addition to being an indicator of value, the transaction price also lets one look into the intention of the buyer when agricultural property is the subject of the transaction. With the mean price of the best soil classes (I, II and IIIa) equal to $4.26 \mathrm{zl} / \mathrm{m}^{2}$ in Poland, means of 70.63 $\mathrm{zl} / \mathrm{m}^{2}$ for the commune and over $200 \mathrm{zl} / \mathrm{m}^{2}$ for the villages of Lipniak and Szerokie show the prices here to be much higher, hence the motivation behind their purchase can be assumed to be different than farming. This is also backed by the size (area) of the purchased real estate. Properties bought with residential purposes in mind tend to be smaller when compared to typical fields used for agricultural production. As shown in Figure 4, areas of properties being the subject of transactions in the commune of Konopnica are much smaller in villages bordering Lublin (especially in Szerokie, Lipniak and Konopnica).

Figure 5 shows diagrams for land prices. Villages adjacent to Lublin in the west and north-west form a zone of high prices. The significantly lower values for Tereszyn can be explained by natural conditions. The area of the village, which is small in itself, consists of about $50 \%$ forests (as also illustrated by Figure 5), which can be a reason behind the smaller number of transactions as compared to Konopnica or even Marynin, as there is not much land to sell that could be conveniently adapted for residential purposes. Land in villages south of Lublin, even quite close to the city, were cheaper, without even mentioning properties on the western edge of the commune, such as Motycz, Sporniak or Pawlin. The latter example of lower prices is more obvious - the factor of distance can play a role here, even if Motycz, for example, as it was shown in Figure 2, is located quite well in relation to the road network. Also, the already mentioned element of fashion and ill-conceived prestige may be important.

It is worth exploring if the close distance and/or good communication network role is not influenced by the factor of time. The road network and vicinity to the city is not all, as what matters is 
the actual time required to commute to the city. This can be long for nearby villages due to the poor quality roads, a rather inconvenient network shape (due to a lake or steep terrain for example) or poor public transport if one considers using it (residents moving from the city to its outskirts are generally quite well-off, but this does not mean they use only private transport to commute to the city; this depends on the quality of public transport and the level of traffic in the city itself; that is why this factor has to be taken into consideration).

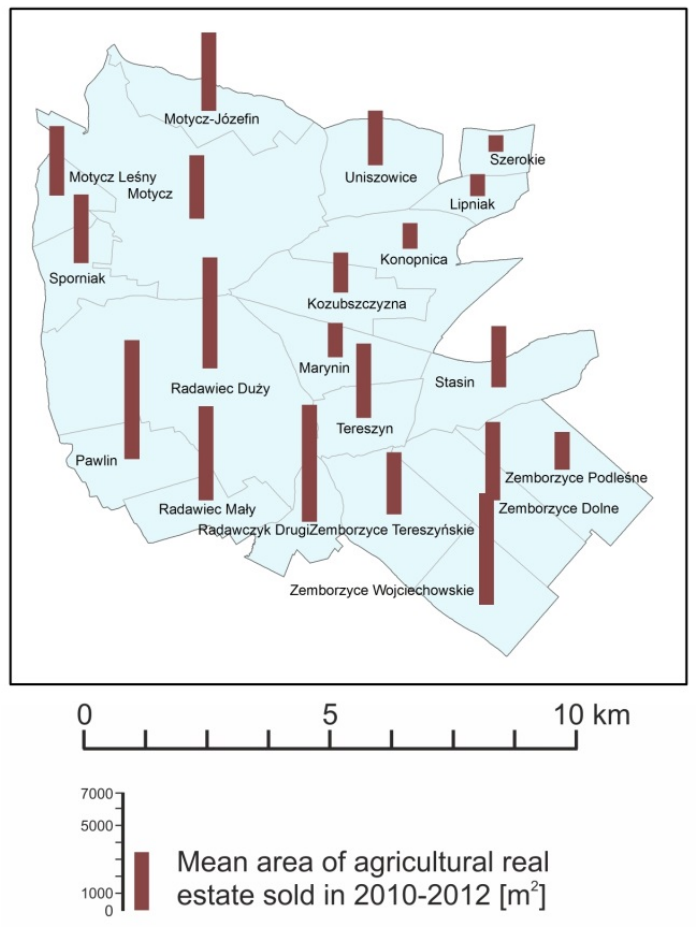

Fig. 4. Mean area of sold/bought real estate in the commune of Konopnica. Source: own study.

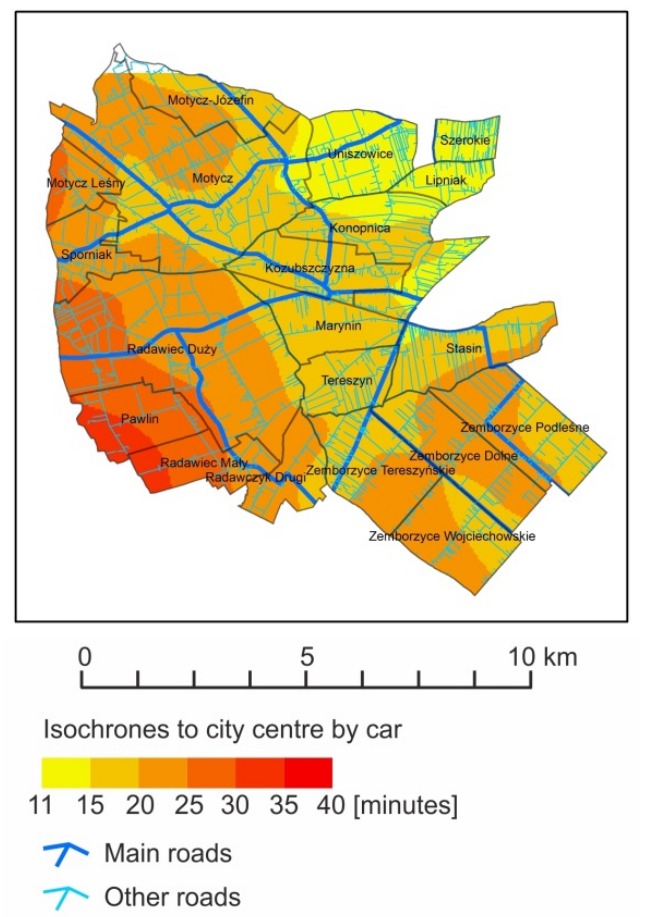

Fig. 6. Isochrones to the city center by car (according to data from Targeo.pl) Source: own study.

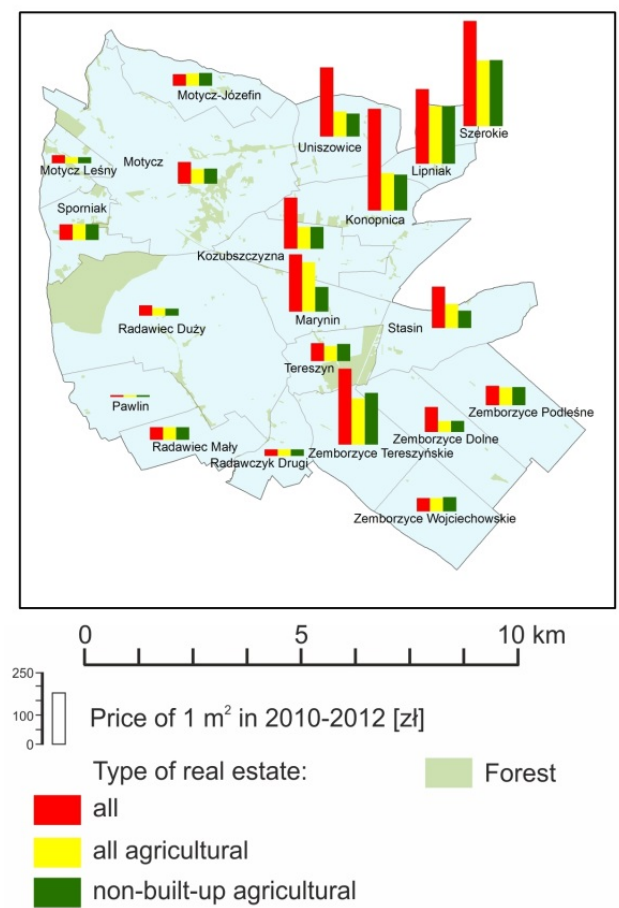

Fig. 5. Prices of real estate in the commune of Konopnica. Source: own study.

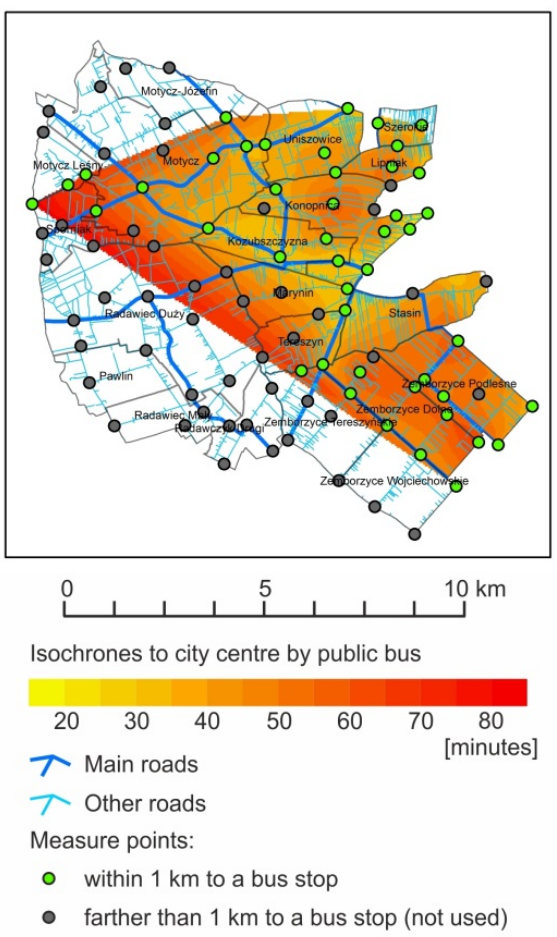

Fig. 7. Isochrones to the city center by public transport (according to data from Targeo.pl). Source: own study. 
Figures 6 and 7 show isochrones of the travel time required to get to the city center (set here as the intersection of Krakowskie Przedmieście, Lipowa and Al. Racławickie). Times were calculated for 96 points using the Targeo (www.targeo.pl) online map and trip planner, with departure time set as 7 am. For car travel, all points were valid, whereas in the case of public transport, additional assumptions had to be made. Points that were farther than $1 \mathrm{~km}$ from the nearest bus stop of public transport to Lublin were not included in the calculations. Combined uses of public transport (trains + buses) were also not included, influencing only Motycz Leśny and Stasin.

The map in Figure 6 helps explain the lower transaction prices recorded in the villages of Zemborzyce. Even though they are located near the border of Lublin, they are not as easily accessible, as far as travel time is concerned, as other nearby villages. The time needed to travel from the villages of Zemborzyce is about equal to that of taken to get to Lublin from areas of Motycz or Sporniak, and prices are more similar to prices of real estate in these villages, than to those of others closer to Lublin, such as Lipniak or Konopnica. On the other hand, good access in terms of distance, roads (national road No. 19) and time does not influence prices in the village of Tereszyn, which has already been mentioned as a specific case due to its small area. Combining this map of isochrones with price data can result in finding out if these factors are connected in terms of statistical analysis. The other map showing time (Fig. 7) depicts access to public transport, with data limited in space to the area covered by public transportation of the city of Lublin. The isochrones seen here are harder to correlate with land prices. They confirm some private transport clues (such as lower prices in Zemborzyce), but show a relatively long time needed to travel by bus from some high price areas of Konopnica; hence these data can only be rather treated as a supplementary source of information.

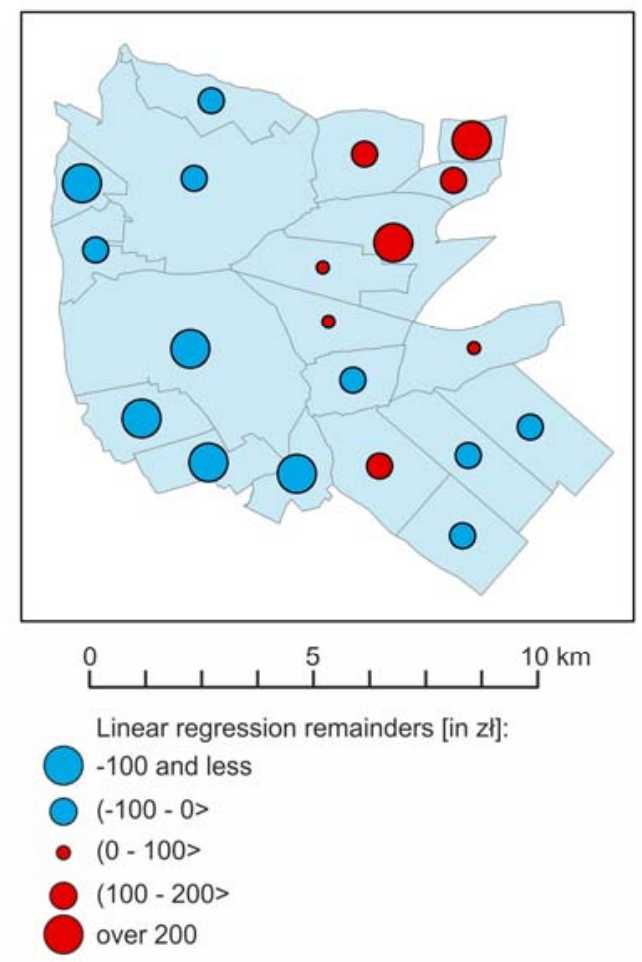

Fig. 8. Remainders of linear regression (travel time according to data from Targeo.pl). Source: own study.

The number of factors, as it was mentioned at the beginning, can be quite large and they may differ from case to case. The use of maps always emphasizes the location factor as being of importance, but particular space-oriented factors are always present in the procedure of real estate appraisal. Besides the general location (village, city) factor, others are mentioned: accessibility (by public and private transport), infrastructure (supplies), environment qualities, the size and shape of the property, etc. (JAKÓBCZYK-GRYSZKIEWICZ 2009, p. 46). Among these factors, the travel time and the distance to the city centre seem to be one of the most significant in the case of suburban estates, and it is their 
influence that is modified by other factors. To find out the extent of this modification, it is worth using the linear regression method. The simple equation of $y=a x+b$ makes it possible to estimate the expected theoretical value of $y$ with a known value of $x$. In the case of the already analyzed time and price, the time is the independent variable, which is not altered, and the price is the dependant variable. It is known for a specific, individual property, but the quotation gives the theoretic value of how the price should change with the single-unit change of time. The difference between theoretical and observed values (remainders) raises the question of what causes this difference. With no other factors than time, the price should be equal to the result of this equation, so the differences are caused by other factors. With maps and knowledge one can find the answer to what factors ought to be taken into consideration.

For the analyzed case, the regression equation takes the form of $y=6.637 x-1.356$, and the calculated remainders are, in some cases, quite large. These values for the individual villages have been presented in Figure 8.

The mean values of travel time for villages were calculated using data seen in Figure 6 (transport by car) and the zonal statistic tool from the Spatial Analyst Toolbox in ArcGIS (all maps here are the results of analyses carried out using ArcGIS 10.2.2). The calculated values were used to compute the regression equation. What can be seen is the fact that, in general, theoretical values near the city border are underestimated and in villages located further away - overestimated. This is a typical trend. The complex influence of the city is the reason behind it, but the image of these remainders on the map confirm tendencies seen on other maps - high prices in Konopnica, Lipniak, and Szerokie, as well as high prices in Zemborzyce Tereszyńskie as opposed to low prices in the other Zemborzyce villages (in both cases, mainly due to transport issues). With other maps portraying potential factors, the answer to the question of the remainder distribution is much easier to answer.

\section{Cartographic methodology}

The important thing to note in the case of maps is the method used. For Fig. 2 to 5 and Fig. 8, this is a diagram. Diagrams located on maps are correct in terms of methodology as long as absolute values are being presented (ŻYSZKOWSKA et al. 2012). They can be shown in forms of different graphs, but bars are the easiest to read, while circles are the best solution in terms of design. This type of presentation is not limited to values (see Fig. 4) but can also include the structure, in the form of structural diagram as seen in Fig. 2 and Fig. 3. The last figure with a diagram (Fig. 8) uses circle diagrams and data classification. The presented values are not specific, but gathered into a few classes with established border values. This map also presents absolute values (remainders expressed in the Polish currency), thus the diagram is an appropriate method here. For relative values (most of all referred to area units), the choropleth method should be used (PASŁAWSKI 2010).

Figures 6 and 7 present values using isochrones - lines connecting equal distances measured in units of time. The raw data were discrete (points) and needed to be transformed into a statistical surface using interpolation. There are many methods of interpolation and the application of a given method depends on data distribution, the type of values, possible result limitations, etc. (URBAŃSKI 2011).

Other cartographic methods less used in this paper are often used in real estate market analyses, especially the signature method to present locations of discrete objects or areas (of distribution). The example of the former can be seen in Fig. 7 with the location of two kinds of measurement points. It can show, for example, the zone of influence of a selected factor.

\section{Summary}

The complex analysis of the local real estate market was not the goal of this paper. The basic aim was the introductory analysis with the use of a cartographic method of research and geomatic tools of GIS to show the applicability of this method. It was proved that maps can be of great use in such analysis, helping to answer certain questions, explain many tendencies and factors influencing prices and find relations between the analyzed factors that may not be visible in other forms (i.e. tables or text). However, as is the case of any tool, maps need to be used properly. The most common problems regard the quality of presentation and methodological errors. GIS makes it tempting to produce maps in just a few clicks, with design, colors and layout offered as a default by the program. This can be easily corrected provided one understands the basics of cartography. Such changes to the presentation are important as a map is a medium of communication and its language (design) has to be clear, 
precise and attractive (FIELD, DEMAJ 2012). Also, the sources of methodological errors may be removed. Here some basic knowledge is also required, not in terms of aesthetic and design principles, but often mainly relating to data manipulation, especially when maps present the statistic outcome of research. The rules for creating choropleth and diagram maps involve a broad range of methods to define classes. The software often proposes solutions which are, as mentioned, easy to just click-andaccept; however, they should be used with understanding and knowledge of what goal one wants to achieve, as it is very easy to falsify data with a bad methodology other than cartographic presentation (SALISZCZEW 1998, pp. 102-103).

Each researcher using maps as a tool of scientific investigation and as a research method should be prepared for facing such problems. Of course this does not mean that one has to be a professional cartographer, but he or she should have an understanding of the basic rules mentioned here. Visualization, the language of maps, methodology and rules of data preparation and mining are important and, when used properly, result in good, informative and appropriate maps. If not - they may lead to a false image, misinterpretation and wrong solutions. That is why it is worth having at least a basic understanding of map tools and science or consulting a professional cartographer.

\section{Acknowledgement}

Research reported in this paper was partly supported by the young researchers and doctoral students fund of the University of Life Sciences in Lublin under the number TKD/MN/1.

I would like to thank dr inż. Grzegorz Wyrykowski and mgr inż. Waldemar Kitta for the preparation of data from the register of notarial deeds of estate sales and purchases.

\section{References}

CICHOCIŃSKI P., 2007, Zastosowanie metod kartograficznych i geostatystycznych do wstępnej analizy rynku nieruchomości (Application of cartographical and geostatistical methods for preliminary analysis of real estate market), Studia i Materiały Towarzystwa Naukowego Nieruchomości, Vol. 15, No. 3-4, pp. 155-166.

CICHOCIŃSKI P., DĄBROWSKI J., 2013, Spatio-temporal analysis of the real estate market using Geographic Information Systems, Real Estate Management and Valuation, Vol. 21, No. 2, pp. 73-82.

Cymerman R., Hopfer A., 2012, Wyceny nieruchomości (Real estate evaluation). Polska Federacja Stowarzyszeń Rzeczoznawców Majątkowych, Warszawa.

FIELD K., DEMAJ D., 2012, Reasserting design relevance in cartography: some concepts, The Cartographic Journal, Vol. 49, No. 1, pp. 70-76.

GLEBY (SOILS), n.d., Oficjalny serwis gminy Konopnica, http://www.konopnica.lubelskie.pl/index.php?option=com_content\&task=view\&id=29\&Itemid= 42 (accessed 12.09.2014).

IWANICKI G., 2012, Wptyw zjawiska suburbanizacji na ksztattowanie przestrzeni na przykładzie obszaru podmiejskiego Lublina(The influence of urban sprawl on spatial design on the example of suburban area of Lublin), in:, Krukowska R. (ed.), Turystyczne, rekreacyjne i geograficzne aspekty ksztattowania przestrzeni. Kartpol, Lublin.

JAKÓBCZYK-GRYSZKIEWICZ J., 2009, Tendencje przestrzenne w kształtowaniu cen ziemi w Polsce po 1990 roku (Spatial tendencies on the real estate market in Poland after 1990). Wydawnictwo Uniwersytetu Łódzkiego, Łódź.

KUCHARSKA-STASIAK E., 2006, Nieruchomość w gospodarce rynkowej (The real estate in a market economy). Wydawnictwo Naukowe PWN, Warszawa.

MAĆKIEWICZ B., 2009, Struktura rynku nieruchomości niezabudowanych w powiecie puławskim (The structure of unbuilt real estate market in powiat of Puławy) , in:, Kacprzak E., Maćkiewicz B. and Motek P. (eds.), Uwarunkowania i rozwój nieruchomości niezabudowanych na obszarach atrakcyjnych turystycznie w powiecie puławskim. Bogucki Wydawnictwo Naukowe, Poznań, pp. 113-122.

MARKOWSKI K. (ed.), 2014, Statystyczny atlas województwa lubelskiego (The statistical atlas of Lublin voivodship). Urząd Statystyczny w Lublinie, Lublin

Powierzchnia i ludność w przekroju terytorialnym w2013 r. (The regional data of area and population in 2013). Główny Urząd Statystyczny, Warszawa.

PASŁAWSKI J. (ed.), 2010, Wprowadzenie do kartografii i topografii (The introduction to cartography and topography). Nowa Era, Wrocław. 
SALISZCZEW K. A., 1998, Kartografia ogólna (The general cartography). Wydawnictwo Naukowe PWN, Warszawa.

TROJAneK M., 2009, Uwarunkowania rozwoju rynku nieruchomości w Polsce (Determinants of the Polish realestate market development) , in:, Kacprzak E., Maćkiewicz B. and Motek P. (eds.), Uwarunkowania $i$ rozwój nieruchomości niezabudowanych na obszarach atrakcyjnych turystycznie w powiecie puławskim. Bogucki Wydawnictwo Naukowe, Poznań, pp. 9-16.

URBAŃSKI J., 2011, GIS $w$ badaniach przyrodniczych (GIS in the environment research). Wydawnictwo Uniwersytetu Gdańskiego, Gdańsk.

WESOŁOWSKA M., 2006, Rozwój budownictwa mieszkaniowego a przemiany przestrzenne wsi województwa lubelskiego (The development of residential housing and spatial changes of villages in the Lublin voivodship), Studia Obszarów Wiejskich, t. X, Komisja Obszarów Wiejskich PTG, Zespół Badań Obszarów Wiejskich IGiPZ PAN, Warszawa.

WITEK T., 1993, Waloryzacja rolniczej przestrzeni produkcyjnej Polski wedtug gmin. Suplement (The valorization of agricultural production space in Polish communes. The appendix). Instytut Uprawy Nawożenia i Gleboznawstwa w Puławach, Puławy.

ŻYSZKOWA W., SPALLEK W., BOROWICZ D., 2012, Kartografia tematyczna (Thematic cartography). Wydawnictwo Naukowe PWN, Warszawa. 